\title{
Acid-base characteristics of the Grass Pond watershed in the Adirondack Mountains of New York State, USA: interactions among soil, vegetation and surface waters
}

\author{
K. M. McEathron ${ }^{1, *}$, M. J. Mitchell ${ }^{1}$, and L. Zhang ${ }^{1}$ \\ ${ }^{1}$ State University College of New York, College of Environmental Science and Forestry, 1 Forestry Drive, Syracuse, \\ New York, 13210, USA \\ * present address: United States Environmental Protection Agency, 290 Broadway, 20th Floor, New York, \\ New York, 10007, USA
}

Correspondence to: K. M. McEathron (kmmceath@gmail.com)

Received: 19 July 2012 - Published in Hydrol. Earth Syst. Sci. Discuss.: 24 September 2012

Revised: 30 May 2013 - Accepted: 3 June 2013 - Published: 9 July 2013

\begin{abstract}
Grass Pond watershed is located within the southwestern Adirondack Mountain region of New York State, USA. This region receives some of the highest rates of acidic deposition in North America and is particularly sensitive to acidic inputs due to many of its soils having shallow depths and being generally base poor. Differences in soil chemistry and tree species between seven subwatersheds were examined in relation to acid-base characteristics of the seven major streams that drain into Grass Pond. Mineral soil pH, stream water BCS (base-cation surplus) and $\mathrm{pH}$ exhibited a positive correlation with sugar maple basal area ( $p=0.055 ; 0.48$ and 0.39 , respectively). Black cherry basal area was inversely correlated with stream water BCS, ANC (acid neutralizing capacity $)_{\mathrm{c}}$ and $\mathrm{NO}_{3}^{-}(p=0.23 ; 0.24$ and 0.20 , respectively). Sugar maple basal areas were positively associated with watershed characteristics associated with the neutralization of atmospheric acidic inputs while in contrast, black cherry basal areas showed opposite relationships to these same watershed characteristics. Canonical correspondence analysis indicated that black cherry had a distinctive relationship with forest floor chemistry apart from the other tree species, specifically a strong positive association with forest floor $\mathrm{NH}_{4}$, while sugar maple had a distinctive relationship with stream chemistry variables, specifically a strong positive association with stream water $\mathrm{ANC}_{\mathrm{c}}, \mathrm{BCS}$ and $\mathrm{pH}$. Our results provide evidence that sugar maple is acid-intolerant or calciphilic tree species and also demonstrate that black cherry is likely an acid-tolerant tree species.
\end{abstract}

\section{Introduction}

The Adirondack Mountain region of New York State is characterized by high elevations, granitic bedrock and is particularly sensitive to acidic atmospheric inputs due to many of the soils in this region having shallow depths and generally being base poor (Ito et al., 2002). Acidic deposition alters soils through the depletion of calcium $\left(\mathrm{Ca}^{2+}\right)$ and other plant nutrient cations $\left(\mathrm{Mg}^{2+}, \mathrm{K}^{+}\right)$and the mobilization of inorganic monomeric aluminum (Al) (Lawrence et al., 1997). Both of these factors may stress forest vegetation and deleteriously affect water quality (Cronan and Grigal, 1995; Horsley et al., 2000; MacAvoy and Bulger, 1995). Countering natural forces that may reduce the deleterious effects of acidic deposition include nutrient recycling, mineral weathering, and the release of exchangeable base cations (McFee et al., 1977).

It is generally recognized that within the northern hardwood forests, sugar maple (Acer saccharum) and other species such as American basswood (Tilia americana), eastern hophornbeam (Ostrya virginiana) and white ash (Fraxinus americana) require base-rich soils and are acid intolerant, while American beech (Fagus grandifolia), and red spruce (Picea rubens) are acid-tolerant species (Christopher et al., 2006; Duchesne et al., 2005; Fujinuma et al., 2005; Mitchell et al., 2003). Sugar maple often grows poorly in soils that are low in $\mathrm{Ca}$ and $\mathrm{Mg}$, high in $\mathrm{Al}$ and have a low $\mathrm{pH}$ (Burns and Honkala, 1990; Van Breemen et al., 1997). Acidintolerant species such as sugar maple have been shown to respond to liming with significantly increased diameter growth, 
improved crown vigor, increased stem basal area increment, and increased seedling density, while acid-intolerant species such as black cherry and American beech have not shown a response to liming (Long et al., 1997; Moore et al., 2012). Previous studies indicate black cherry (Prunus serotina) might be an acid-tolerant species although research on this tree species in relation to site acid-base characteristics is very limited (Aguilar and Arnold, 1985; Godefroid et al., 2005; Long et al., 2009; Lorenz et al., 2004).

In addition to species-specific nutrient requirements, various tree species will differ in their cycling of nutrients and base cations, which may result in differences in nutrients and base cation concentrations of soils in forest stands. For instance, sugar maple litter generally has low lignin and $\mathrm{C}: \mathrm{N}$ concentrations and relatively high $\mathrm{N}$ concentrations causing rapid decomposition and higher rates of net nitrification compared to American beech, red maple, black cherry and red spruce that have relatively high lignin concentrations (Aber et al., 2003; Adams and Angradi, 1996; Lovett and Rueth, 1999; Melillo et al., 1982; Mitchell et al., 1992; Page and Mitchell, 2008). In general, it has been suggested that there may be connections between tree species, soil and litter nutrient cycling on sites, whereby tree species with highly labile litter yield high rates of nutrient cycling and soil nutrient concentrations (Hobbie, 1992; Page and Mitchell, 2008; Van Breemen, 1995). Additionally, Dijsktra (2003) found that in forest stands in Connecticut net $\mathrm{Ca}$ mineralization and $\mathrm{Ca}$ concentrations in the mineral soil was significantly higher beneath sugar maple than beneath beech and white ash.

Within the Adirondack Park, sulfate and nitrate concentrations in precipitation generally decrease from the southwest to the northeast and increase with elevation (Ito et al., 2002). Stream and lake nitrate concentrations are generally consistent with this pattern of nitrogen deposition with decreasing values from west to east across New York and New England (Aber et al., 2003). Grass Pond watershed, located within the southwestern Adirondack Mountains region of New York, receives some of the highest rates of acidic deposition in the region (Driscoll et al., 1991, 2003; Ito et al., 2002). Despite receiving similar rates of acidic deposition, subwatersheds within Grass Pond watershed differentially neutralize acidic surface waters (Ito et al., 2007). Understanding the relationships between watershed characteristics and acid neutralizing capacity provides insight into the sensitivity or resilience of watersheds and the relative importance of different tree species with respect to the deleterious impacts of acidic deposition and the potential for different forest management scenarios and strategies.

The objective of our study was to evaluate the relationships between stream and soil acid-base chemistry as a function of the presence and abundance of acid-tolerant and acidintolerant tree species within Grass Pond subwatersheds. Black cherry and sugar maple tree species were the primary focus of our research study due to the presence of both tree species within Grass Pond subwatersheds, the economic

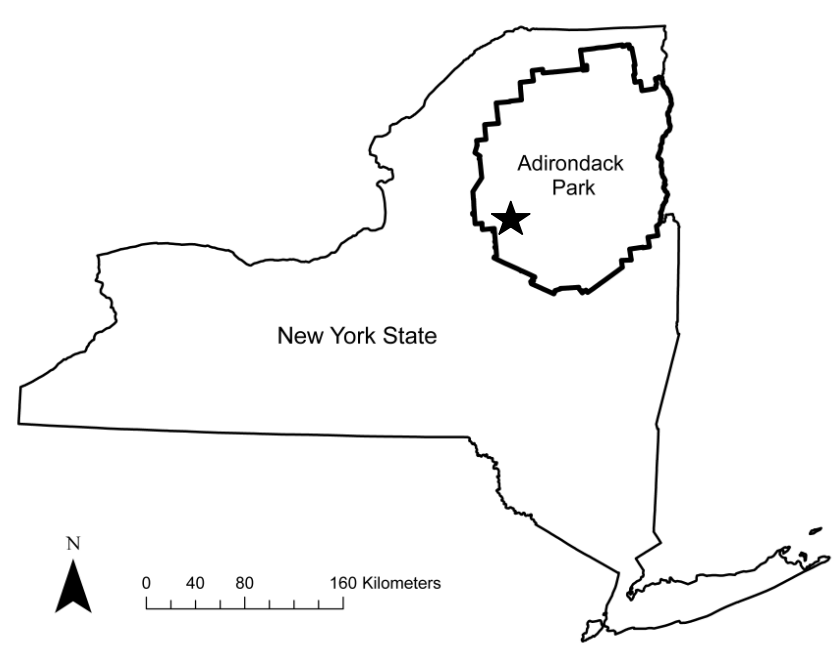

Fig. 1. The Adirondack Park located within New York State. The star indicates the location of Grass Pond watershed in the southwestern region of the Adirondacks.

importance of black cherry for the timber industry and sugar maple for the maple syrup industry as well as the noted decline of sugar maple trees in a number of regions including the Adirondacks (Burns and Honkala, 1990; Van Breemen et al., 1997). Recent studies have suggested the importance of black cherry especially in sites with low base status (Aguilar and Arnold, 1985; Godefroid et al., 2005; Lorenz et al., 2004). The researchers predicted that acid-tolerant tree species, such as black cherry, would exhibit an inverse relationship with soil and stream base cation concentrations and stream acid neutralizing capacity while acid-intolerant tree species, such as sugar maple, would exhibit a positive relationship with soil and stream base cation concentrations and stream acid neutralizing capacity.

\section{Methods}

\subsection{Site description}

Grass Pond watershed is located within the Ha-De-Ron-Dah Wilderness Area at $43^{\circ} 41^{\prime} 25^{\prime \prime} \mathrm{N}, 75^{\circ} 3^{\prime} 54^{\prime \prime} \mathrm{W}$ in the southwestern Adirondack Mountains of New York State. The watershed is divided into seven adjacent subwatersheds that exhibit substantial differences in stream water acid-base chemistry (Ito et al., 2007) (Fig. 1). The entire Grass Pond watershed has an area of 237 ha with elevation ranges from 552 to $684 \mathrm{~m}$. The parent material has variable thickness and is derived from glacial till. Soils are predominantly Spodosols. Vegetation is typical of a northern hardwood mixed forest containing red maple, yellow birch (Betula alleghaniensis), American beech, and sugar maple, with some black cherry, red spruce and eastern hemlock. A more detailed description of the seven Grass Pond subwatersheds is available in Ito et al. (2007). 


\subsection{Site history}

In the 1800 s to the early 1900 s, large portions of the southwestern Adirondacks were cleared for timber harvest and for agriculture (Schneider, 1998). It is likely that during this time landowners logged Grass Pond watershed. In 1903, a 25000 acre fire burned the Ha-De-Ron-Dah area (Gray, 1995). From 1909 to 1981, New York State acquired parcels of land including the Grass Pond watershed and in 1986 the State designated this area as the 26600 acre Ha-De-Ron-Dah Wilderness Area (Gray, 1995).

\subsection{Sampling}

\subsubsection{Stream water}

In October 2008, a period for which discharge was reflecting base flow conditions, 37 stream water samples were collected along an elevational gradient along the seven streams located within the Grass Pond watershed. Stream samples were collected starting at each stream inlet to Grass Pond and taken at $\sim 150 \mathrm{~m}$ longitudinal increments going upstream. Streams 2 and 5 had two main tributaries that joined and drained into the inlet to Grass Pond. For streams 2 and 5, samples were collected at the inlet downstream from where the two tributaries joined as well as upstream both tributaries. Stream water samples were collected and stored in $250 \mathrm{~mL}$ polyethylene bottles at $4{ }^{\circ} \mathrm{C}$ until chemical analysis. Stream samples were filtered through $0.45 \mu \mathrm{m} \mathrm{HV}$ (high volume) membrane filters to remove particulate matter prior to analysis.

\subsubsection{Vegetation}

Tree vegetation surveys were conducted during August, September and October 2008. Each subwatershed was sampled using $9 \mathrm{~m}$ radius plots selected from a grid of transects, accounting for $\sim 1 \%$ of the area of each subwatershed with a total of 80 plots. All tree species $\geq 5 \mathrm{~cm}$ in diameter at $1.4 \mathrm{~m}$ above the ground (dbh, diameter at breast height) within each selected sample plot were identified and dbh measured to determine total and relative (\%) basal area for each species within plots and subwatersheds.

\subsubsection{Soil}

Soil samples were collected at Grass Pond watershed in October 2008 within the selected vegetation plots. In each plot, the forest floor (Oe/Oa horizon) and upper mineral soil (0$10 \mathrm{~cm}$ ) were sampled from three locations, homogenized in a bucket and a sub-sample was sealed in a polyethylene bag. The forest floor was sampled by removing litter (Oi horizon) and by cutting a small square, approximately $20 \mathrm{~cm} \times 20 \mathrm{~cm}$, into the Oe/Oa horizon with a knife. The upper mineral soil was sampled using a "bulb planter corer" under the location of the forest floor sample. All collected samples were kept refrigerated at $4{ }^{\circ} \mathrm{C}$ until further sample preparation and chemical analysis. A total of 59 mineral soil and 63 forest floor samples were collected. At locations where insufficient soil development occurred, samples were not collected and at locations with forest floor soil layers deeper than approximately a meter, mineral soil samples were not collected.

\subsection{Sample analysis}

\subsubsection{Stream water}

Stream water samples were analyzed for $\mathrm{pH}$ potentiometrically, using a MI-410 combination $\mathrm{pH}$ electrode (Microelectrodes, Inc.) in conjunction with an Accumet ${ }^{\circledR}$, AR50, dual channel $\mathrm{pH} / \mathrm{ion} /$ conductivity meter. Stream water samples were analyzed for dissolved organic carbon (DOC) by persulfate oxidation using a Tekmar Phoenix 8000 carbon analyzer. Ammonium $\left(\mathrm{NH}_{4}\right)$ and total $\mathrm{N}$ were determined using the Autoanalyzer3. Stream water samples were analyzed for cation ( $\mathrm{Al}, \mathrm{Ca}, \mathrm{K}, \mathrm{Mg}, \mathrm{Na}$ and $\mathrm{Si}$ ) concentrations using a Perkin-Elmer Optima DIV $3300^{\circledR}$, inductively coupled plasma atomic emission spectrophotometer (ICP-AES) and for anion $\left(\mathrm{Cl}^{-}, \mathrm{NO}_{3}^{-}\right.$and $\left.\mathrm{SO}_{4}^{2-}\right)$ concentrations using a Dionex ICS-2000 ${ }^{\circledR}$ ion chromatograph (IC).

Stream water acid neutralizing capacity $\left(\mathrm{ANC}_{\mathrm{c}}\right)$ was calculated using the equation

$$
\begin{aligned}
\mathrm{ANC}_{\mathrm{c}} & =\left[\mathrm{Ca}^{2+}\right]+\left[\mathrm{Mg}^{2+}\right]+\left[\mathrm{Na}^{+}\right]+\left[\mathrm{K}^{+}\right]-\left[\mathrm{Cl}^{-}\right] \\
& -\left[\mathrm{NO}_{3}^{-}\right]-\left[\mathrm{SO}_{4}^{2-}\right],
\end{aligned}
$$

in which concentrations are expressed in $\mu \mathrm{eq} \mathrm{L}^{-1}$.

The base-cation surplus (BCS) was calculated using the equation

$$
\begin{aligned}
\mathrm{BCS} & =\left[\mathrm{Ca}^{2+}\right]+\left[\mathrm{Mg}^{2+}\right]+\left[\mathrm{Na}^{+}\right]+\left[\mathrm{K}^{+}\right]-\left[\mathrm{Cl}^{-}\right] \\
& -\left[\mathrm{NO}_{3}^{-}\right]-\left[\mathrm{SO}_{4}^{2-}\right]-\left[\mathrm{RCOO}_{\mathrm{s}}^{-}\right],
\end{aligned}
$$

in which concentrations are expressed in $\mu$ eq $\mathrm{L}^{-1}$ (Lawrence et al., 2007). In the equation for $\mathrm{BCS},\left[\mathrm{RCOO}_{\mathrm{s}}^{-}\right]$equals the concentration of strong organic anions. Estimates of the contribution of organic anions to a solution charge were calculated using the equation $\left[\mathrm{RCOO}_{\mathrm{s}}^{-}\right]=0.071[\mathrm{DOC}]-2.1$ (Lawrence et al., 2007). Where $\left[\mathrm{RCOO}_{\mathrm{s}}^{-}\right]$is the $\left(\mu \mathrm{eq} \mathrm{L}^{-1}\right.$ ) organic anion concentration, and [DOC] is the $\left(\mu \mathrm{eq} \mathrm{L}^{-1}\right)$ dissolved organic carbon concentration.

\subsubsection{Soil}

Fresh forest floor and mineral soil samples were homogenized and sieved to $6.4 \mathrm{~mm}$ to remove coarse fragments. Percent organic matter was determined as loss-on-ignition at $470{ }^{\circ} \mathrm{C}$ for $16 \mathrm{~h}$ (Wilde et al., 1972). Soil $\mathrm{pH}$ was determined potentiometrically in $2: 1$ slurry of 0.01 molar $\mathrm{CaCl}_{2}$ : fresh soil sample (Sparks et al., 1996). 
Total extractable $\mathrm{N}$ and $\mathrm{NH}_{4}^{+}$were determined by combining soil samples (approximately $10 \mathrm{~g}$ for forest floor and $20 \mathrm{~g}$ for mineral soil) with $70 \mathrm{~mL}$ of 2 molar $\mathrm{KCl}$. The solution was then shaken for $1 \mathrm{~h}$, filtered through Whatman $42^{\circledR}$ ashless filter paper (pore size $2.5 \mu \mathrm{m}$ ), rinsed three times and then raised to $100 \mathrm{~mL}$ volume with 2 molar $\mathrm{KCl}$ (modified from Blume et al., 1990; Page and Mitchell, 2008). A $20 \mathrm{~mL}$ sub-sample of the filtrate was decanted and analyzed using continuous flow colorimetry on a Bran-Luebbe AutoAnalyzer ${ }^{\circledR}$ for $\mathrm{NH}_{4}^{+}$and total $\mathrm{N}$.

Forest floor soil samples were ground in a Wiley ${ }^{\circledR}$ mill using a \#20 $(0.85 \mathrm{~mm})$ screen and were analyzed for percent $\mathrm{C}$ and $\mathrm{N}$ on a Thermo Electron Flash EA $1112^{\circledR}$ elemental analyzer to determine the $\mathrm{C}: \mathrm{N}$ mass ratio. Forest floor soil samples were analyzed for total elemental $\mathrm{Al}, \mathrm{Ca}, \mathrm{K}, \mathrm{Mg}$, $\mathrm{Na}$, and $\mathrm{P}$ by ashing a $1 \mathrm{~g}$ homogenized sample at $470^{\circ} \mathrm{C}$ for $16 \mathrm{~h}$. The ash was then dissolved in $10 \mathrm{~mL}$ of 6 molar $\mathrm{HCl}$, evaporated to dryness on a hot plate, re-dissolved in $10 \mathrm{~mL}$ of 6 molar $\mathrm{HCl}$, filtered through a Whatman $42^{\circledR}$ ashless filter paper, rinsed three times with deionized, distilled water (DDW) and raised to $100 \mathrm{~mL}$ with DDW (Page and Mitchell, 2008; modified from Sparks et al., 1996). Total elemental concentrations ( $\mathrm{Al}, \mathrm{Ca}, \mathrm{K}, \mathrm{Mg}, \mathrm{Na}$, and $\mathrm{P}$ ) were then determined using ICP-AES.

Mineral soils were analyzed for exchangeable elements (Al, $\mathrm{Ca}, \mathrm{K}, \mathrm{Mg}, \mathrm{Na}$, and $\mathrm{Si}$ ) by extracting approximately $10 \mathrm{~g}$ dry soil in $50 \mathrm{~mL}$ of $1 \mathrm{M} \mathrm{NH} \mathrm{NH}_{4} \mathrm{Cl}$. The solution was then filtered through a Whatman $42^{\circledR}$ ashless filter paper, rinsed three times with $10 \mathrm{~mL}$ of 1 molar $\mathrm{NH}_{4} \mathrm{Cl}$, and then raised to a volume of $100 \mathrm{~mL}$ with 1 molar $\mathrm{NH}_{4} \mathrm{Cl}$ (Blume et al., 1990). Samples were then frozen until analyzed for exchangeable cation concentrations using ICP-AES.

\subsection{Statistical analyses}

Pearson correlations were used to determine the significance of relationships between soil chemical measurements and tree species basal areas, as well as between stream chemistry and tree species basal areas. Analyses were based on sample sizes of 60 and 55 for the forest floor and mineral soil, respectively, after removal of 7 outliers ( $<6 \%$ of all samples) to help facilitate multivariate analysis assumptions. We also did the statistical determinations with the outliers and found there was no substantive effect on the overall results. The plot data and stream chemistry were averaged by the 7 subwatersheds for analysis (sample size of 7). Variables used in the analysis include the chemical constituents of the forest floor, mineral soil, and stream $\left(\mathrm{pH}, \mathrm{Ca}^{2+}\right.$, etc.) and the total basal areas of specific tree species. For interpreting " $p$ values" we followed the approach recommended by Sterne and Smith (2001).

Canonical correspondence analysis (CCA) is a wellestablished multivariate technique to analyze speciesenvironment relationships (Ter Braak, 1986; Khattree and
Naik, 2000). It is a two-step gradient analysis, in which ordination axes are extracted from species abundance data, followed by the identifying gradient from environment variables. Thus, the dominant pattern of variation in species community can be directly related to variation in environmental variables. The results of CCA are commonly displayed by a biplot, which is a graphical presentation of the data matrix by two sets of plots overlaid on the same coordinate system, one plot representing species and the other plot representing environment variables (Hodge and Naik, 1999). In addition, the percentage variations accounted for by the two ordination axes were computed as the proportion of the first two eigen values to the sum of all eigen values of species-environment correlations (Ter Braak, 1986).

In our study, CCA was used to relate tree species basal areas to forest floor, mineral soil, and stream chemistry, respectively. In the resultant biplots, species are shown as points, while chemical variables are represented by arrows from the origin of the biplot. Important chemical variables tend to be represented by longer arrows than less important chemical variables, and the relative locations of species points to the direction of arrows (chemical variables) indicate the association and correlation of each species with respect to each chemical variable (Ter Braak, 1986; Khattree and Naik, 2000).

\subsection{GIS mapping}

The density analysis function in the Spatial Analyst tool of ArcMap version 8.3 (ESRI, Inc.) was used to create maps that geographically distribute tree species basal area data collected from each plot and expand it throughout the entire watershed. This allowed for a visual representation of tree species and stream chemistry data.

\section{Results}

\subsection{Watershed characteristics}

The major tree species within Grass Pond watershed included American beech, black cherry, eastern hemlock, red maple, red spruce, striped maple (Acer pensylvanicum), sugar maple and yellow birch (Fig. 2). Red maple and American beech were the most abundant species within the watershed with 28 and $34 \%$ relative basal area, respectively. Black cherry, with $4 \%$ relative basal area, occurred in nine plots, primarily in the upper elevations of subwatersheds 4 and 5. Sugar maple, with $9 \%$ relative basal area occurred primarily in subwatershed 3.

Within Grass Pond watershed, streams 4, 5, 6 and 7 were acidic with $\mathrm{ANC}<0 \mu \mathrm{eq} \mathrm{L}^{-1}$ (Table 1 and Fig. 3a). All stream sample sites had moderate to low nitrate levels $\left(<40 \mu \mathrm{eq} \mathrm{L} \mathrm{L}^{-1}\right)$ (Table 1). Regional surveys of surface waters in forested watersheds in the northeast United States have suggested that nitrate concentrations range from 0 to 
Table 1. Grass Pond stream chemistry means (standard deviation) analyzed from stream samples collected in October 2008.

\begin{tabular}{lrrrcrr}
\hline Stream & $n$ & $\begin{array}{r}\mathrm{ANC}_{\mathrm{c}} \\
\left(\mu \mathrm{eqL} \mathrm{L}^{-1}\right)\end{array}$ & $\begin{array}{r}\mathrm{BCS} \\
\left(\mu \mathrm{eq} \mathrm{L}^{-1}\right)\end{array}$ & $\begin{array}{c}\mathrm{pH} \\
(\text { units })\end{array}$ & $\begin{array}{r}\mathrm{DOC} \\
\left(\mu \mathrm{mol} \mathrm{CL} \mathrm{C}^{-1}\right)\end{array}$ & $\begin{array}{r}\mathrm{NO}_{3}^{-} \\
\left(\mu \mathrm{eq} \mathrm{L}{ }^{-1}\right.\end{array}$ \\
\hline 1 & 2 & $35(15)$ & $11(18)$ & $6.4(0.06)$ & $367(45)$ & $7(3)$ \\
2 & 3 & $55(47)$ & $40(47)$ & $6.2(0.14)$ & $244(40)$ & $7(4)$ \\
3 & 6 & $152(19)$ & $122(18)$ & $6.8(0.09)$ & $459(37)$ & $22(2)$ \\
4 & 7 & $-6(52)$ & $-31(53)$ & $5.4(0.86)$ & $374(26)$ & $12(4)$ \\
5 & 7 & $-33(13)$ & $-65(21)$ & $4.9(0.19)$ & $485(139)$ & $4(3)$ \\
6 & 6 & $-38(8)$ & $-68(11)$ & $4.9(0.10)$ & $449(74)$ & $10(2)$ \\
7 & 6 & $-42(8)$ & $-72(8)$ & $4.7(0.04)$ & $457(43)$ & $1(1)$ \\
\hline
\end{tabular}

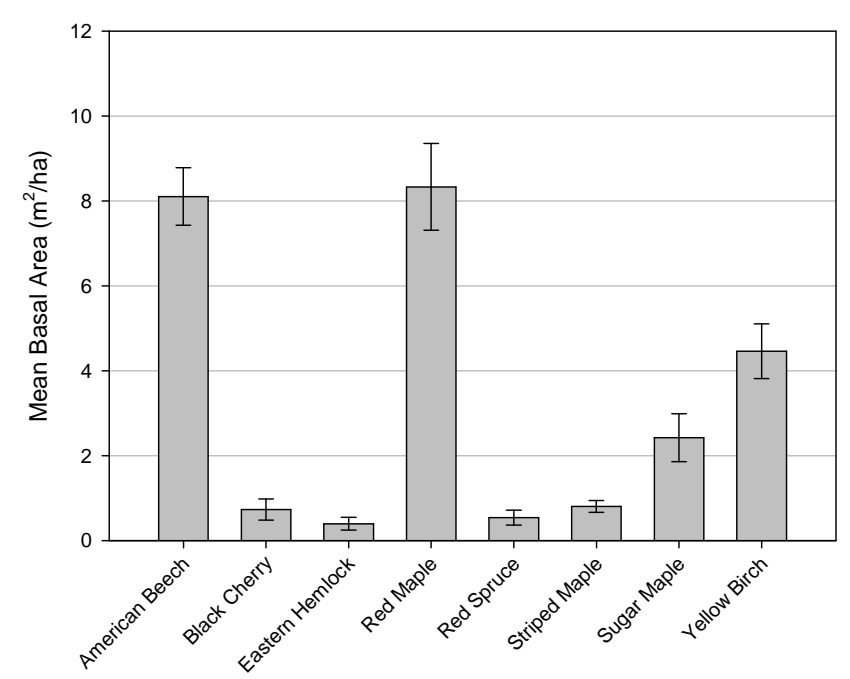

Fig. 2. Grass Pond watershed mean tree species total basal area $\left(\mathrm{m}^{2} \mathrm{ha}^{-1}\right)$ calculated from plot data collected AugustOctober 2008. Bars indicate one standard error.

$60 \mu \mathrm{eq} \mathrm{L}^{-1}$ (Aber et al., 2003) and hence the nitrate values for the streams of the Grass Pond watershed were within the low to moderate range. Only two stream sample sites exhibited high DOC levels (> $600 \mu \mathrm{mol} \mathrm{C} \mathrm{L}{ }^{-1}$ ) (Driscoll and Newton, 1990), which were located in the headwater sample sites of stream 5 (Table 1).

Forest floor and mineral soils within Grass Pond watershed were generally acidic with mean $\mathrm{pH}$ values less than 4.0 (Fig. 3b). Forest floor mean $\mathrm{C}: \mathrm{N}$ mass ratios were below 20 indicating elevated nitrogen levels (Driscoll et al., 2003). It has generally been established that monomeric Al concentrations in soil and surface waters $>10 \mu \mathrm{mol} \mathrm{L}^{-1}$ are toxic (Driscoll et al., 2001). The concentrations of exchangeable Ca found in the Grass Pond watershed soils were within the range $\left(<0.1 \mathrm{mg} \mathrm{Cag}^{-1}\right.$ soil) that has been attributed to surface water acidification throughout the Adirondacks (Table 2). These relatively low Ca soil concentrations were also coupled with high Al soil concentrations in the Grass Pond watershed (Table 2) (Sullivan et al., 2006).
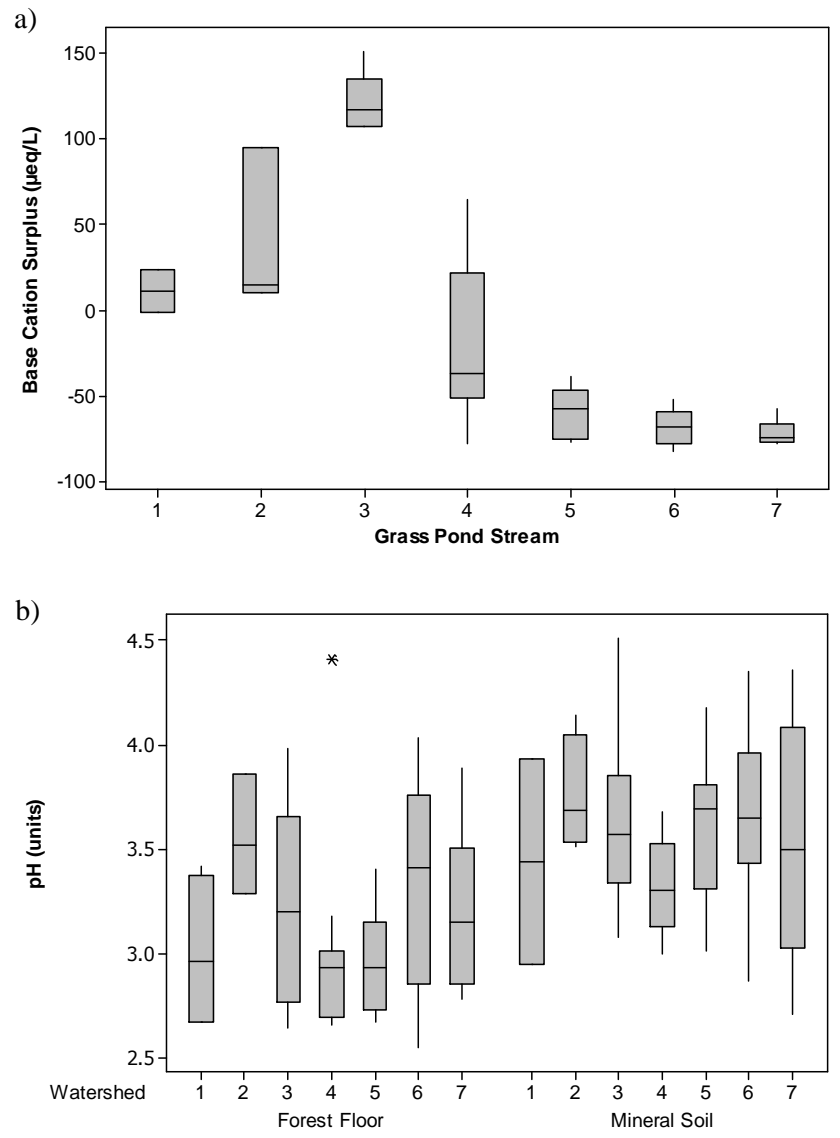

Fig. 3. (a) Base-cation surplus means $\left(\mu \mathrm{eq} \mathrm{L}^{-1}\right)$ for each Grass Pond stream with bars indicating one standard deviation. Values $\leq 0 \mu \mathrm{eq} \mathrm{L}^{-1}$ indicate a low capacity to neutralize acidic inputs. (b) Forest floor and mineral soil sample $\mathrm{pH}$ (units) for each Grass Pond subwatershed.

\subsection{Sugar maple site characteristics}

Mineral soil $\mathrm{pH}$ and sugar maple basal area exhibited a positive correlation $(r=0.26, p=0.055)$ (Table 3). Stream water BCS and $\mathrm{pH}$ were positively correlated with sugar maple basal area ( $r=0.32, p=0.48$ and $0.39,0.39$, respectively) (Fig. 4a and Table 4). Stream water DOC concentrations 
Table 2. Forest floor (total) and mineral soil (exchangeable) chemistry means (standard deviation) for sample plots within Grass Pond subwatersheds.

\begin{tabular}{|c|c|c|c|c|c|c|c|c|c|c|c|}
\hline \multirow{2}{*}{$\begin{array}{c}\text { Sub- } \\
\text { watershed }\end{array}$} & \multicolumn{6}{|c|}{ Forest floor } & \multicolumn{5}{|c|}{ Mineral soil } \\
\hline & $n$ & $\begin{array}{c}\mathrm{pH} \\
\text { (units) }\end{array}$ & $\begin{array}{c}\mathrm{Al} \\
\left(\mathrm{mg} \mathrm{g}^{-1}\right)\end{array}$ & $\begin{array}{c}\mathrm{Ca} \\
\left(\mathrm{mg} \mathrm{g}^{-1}\right)\end{array}$ & $\begin{array}{c}\mathrm{NH}_{4} \\
(\mu \mathrm{mol} \\
\left.\mathrm{Ng}^{-1}\right)\end{array}$ & $\begin{array}{l}\mathrm{C}: \mathrm{N} \\
\text { (mass } \\
\text { ratio) }\end{array}$ & $n$ & $\begin{array}{c}\mathrm{pH} \\
\text { (units) }\end{array}$ & $\begin{array}{c}\mathrm{Al} \\
\left(\mathrm{mg} \mathrm{g}^{-1}\right)\end{array}$ & $\begin{array}{c}\mathrm{Ca} \\
\left(\mathrm{mg} \mathrm{g}^{-1}\right)\end{array}$ & $\begin{array}{c}\mathrm{NH}_{4} \\
(\mu \mathrm{mol} \\
\left.\mathrm{Ng}^{-1}\right)\end{array}$ \\
\hline 1 & 4 & $\begin{array}{c}3.0 \\
(0.4)\end{array}$ & $\begin{array}{c}2.28 \\
(0.45)\end{array}$ & $\begin{array}{c}1.95 \\
(1.09)\end{array}$ & $\begin{array}{c}0.58 \\
(0.39)\end{array}$ & $\begin{array}{l}19.3 \\
(1.8)\end{array}$ & 2 & $\begin{array}{c}3.4 \\
(0.7)\end{array}$ & $\begin{array}{c}0.23 \\
(0.06)\end{array}$ & $\begin{array}{c}0.27 \\
(0.30)\end{array}$ & $\begin{array}{c}0.72 \\
(0.37)\end{array}$ \\
\hline 2 & 3 & $\begin{array}{c}3.6 \\
(0.3)\end{array}$ & $\begin{array}{c}11.0 \\
(13.9)\end{array}$ & $\begin{array}{c}0.78 \\
(0.21)\end{array}$ & $\begin{array}{c}0.36 \\
(0.084)\end{array}$ & $\begin{array}{l}18.1 \\
(2.1)\end{array}$ & 4 & $\begin{array}{c}3.8 \\
(0.3)\end{array}$ & $\begin{array}{c}0.36 \\
(0.19)\end{array}$ & $\begin{array}{c}0.09 \\
(0.05)\end{array}$ & $\begin{array}{c}0.39 \\
(0.15)\end{array}$ \\
\hline 3 & 16 & $\begin{array}{c}3.3 \\
(0.5)\end{array}$ & $\begin{array}{c}3.97 \\
(2.37)\end{array}$ & $\begin{array}{c}1.21 \\
(0.81)\end{array}$ & $\begin{array}{c}0.53 \\
(0.34)\end{array}$ & $\begin{array}{l}18.9 \\
(1.4)\end{array}$ & 13 & $\begin{array}{c}3.6 \\
(0.4)\end{array}$ & $\begin{array}{c}0.39 \\
(0.23)\end{array}$ & $\begin{array}{c}0.13 \\
(0.18)\end{array}$ & $\begin{array}{c}0.45 \\
(0.19)\end{array}$ \\
\hline 4 & 11 & $\begin{array}{c}3.0 \\
(0.5)\end{array}$ & $\begin{array}{c}4.59 \\
(6.91)\end{array}$ & $\begin{array}{c}1.18 \\
(0.64)\end{array}$ & $\begin{array}{c}0.50 \\
(0.50)\end{array}$ & $\begin{array}{l}18.7 \\
(1.6)\end{array}$ & 9 & $\begin{array}{c}3.3 \\
(0.2)\end{array}$ & $\begin{array}{c}0.31 \\
(0.17)\end{array}$ & $\begin{array}{c}0.15 \\
(0.14)\end{array}$ & $\begin{array}{c}0.46 \\
(0.14)\end{array}$ \\
\hline 5 & 7 & $\begin{array}{c}3.0 \\
(0.3)\end{array}$ & $\begin{array}{c}4.54 \\
(3.03)\end{array}$ & $\begin{array}{c}1.27 \\
(0.60)\end{array}$ & $\begin{array}{c}0.62 \\
(0.64)\end{array}$ & $\begin{array}{l}19.6 \\
(1.1)\end{array}$ & 8 & $\begin{array}{c}3.6 \\
(0.4)\end{array}$ & $\begin{array}{c}0.32 \\
(0.15)\end{array}$ & $\begin{array}{c}0.10 \\
(0.05)\end{array}$ & $\begin{array}{c}0.44 \\
(0.23)\end{array}$ \\
\hline 6 & 11 & $\begin{array}{c}3.3 \\
(0.5)\end{array}$ & $\begin{array}{c}11.1 \\
(10.8)\end{array}$ & $\begin{array}{c}1.03 \\
(0.76)\end{array}$ & $\begin{array}{c}0.54 \\
(0.51)\end{array}$ & $\begin{array}{l}19.1 \\
(2.0)\end{array}$ & 11 & $\begin{array}{c}3.7 \\
(0.4)\end{array}$ & $\begin{array}{c}0.39 \\
(0.22)\end{array}$ & $\begin{array}{c}0.09 \\
(0.08)\end{array}$ & $\begin{array}{c}0.37 \\
(0.15)\end{array}$ \\
\hline 7 & 8 & $\begin{array}{c}3.2 \\
(0.4)\end{array}$ & $\begin{array}{c}3.86 \\
(4.18)\end{array}$ & $\begin{array}{c}1.53 \\
(0.88)\end{array}$ & $\begin{array}{c}0.53 \\
(0.55)\end{array}$ & $\begin{array}{l}19.8 \\
(1.3)\end{array}$ & 8 & $\begin{array}{c}3.5 \\
(0.6)\end{array}$ & $\begin{array}{c}0.27 \\
(0.14)\end{array}$ & $\begin{array}{c}0.12 \\
(0.09)\end{array}$ & $\begin{array}{c}0.51 \\
(0.21)\end{array}$ \\
\hline
\end{tabular}
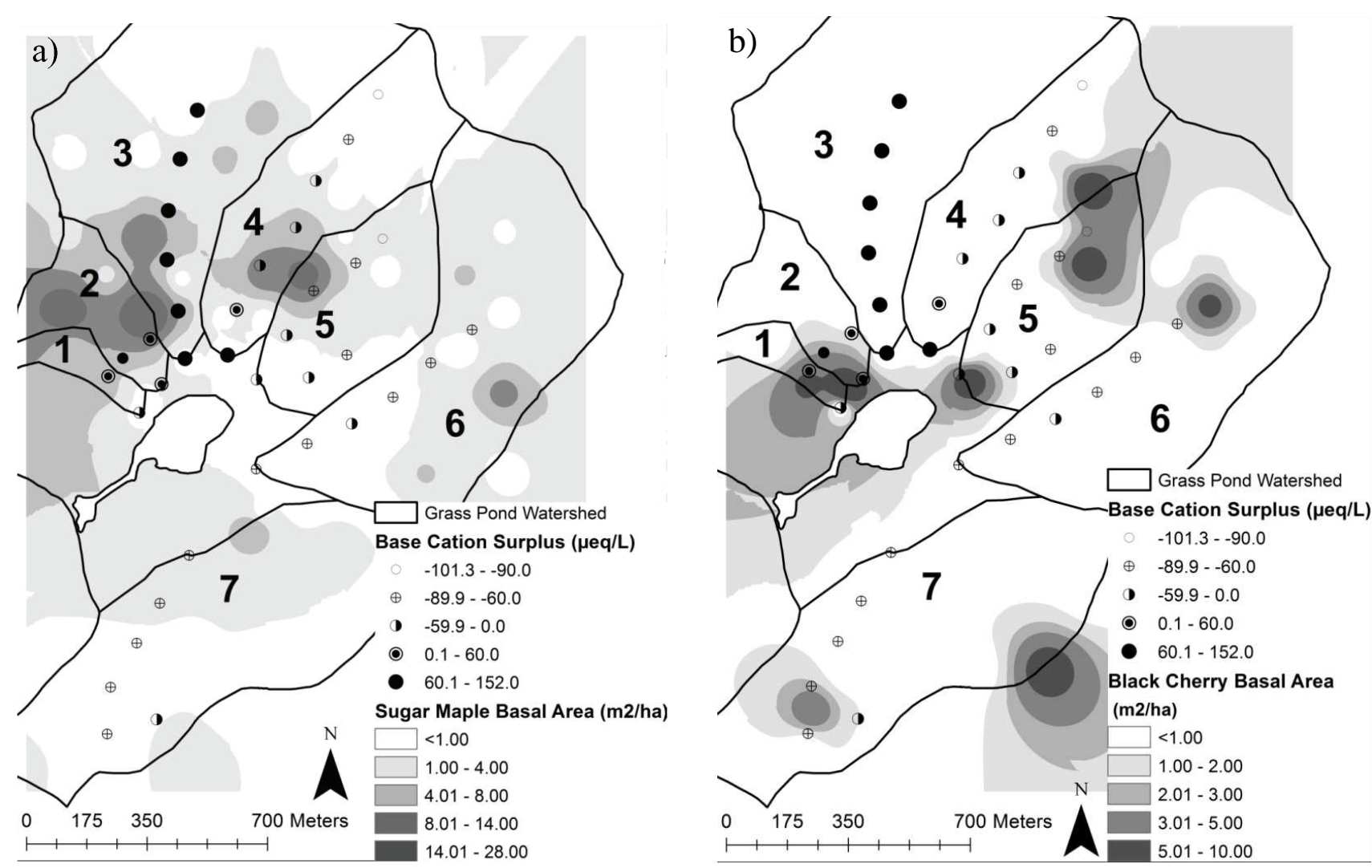

Fig. 4. (a) Stream BCS and sugar maple basal area upstream from the sample location. (b) Stream BCS and black cherry basal area upstream from the stream sample location. 
Table 3. Factor analysis. Forest floor data and tree species basal area Pearson correlation coefficients $(n=60)$ and mineral soil data and tree species basal area Pearson correlation coefficients $(n=55)$ with $p$ values.

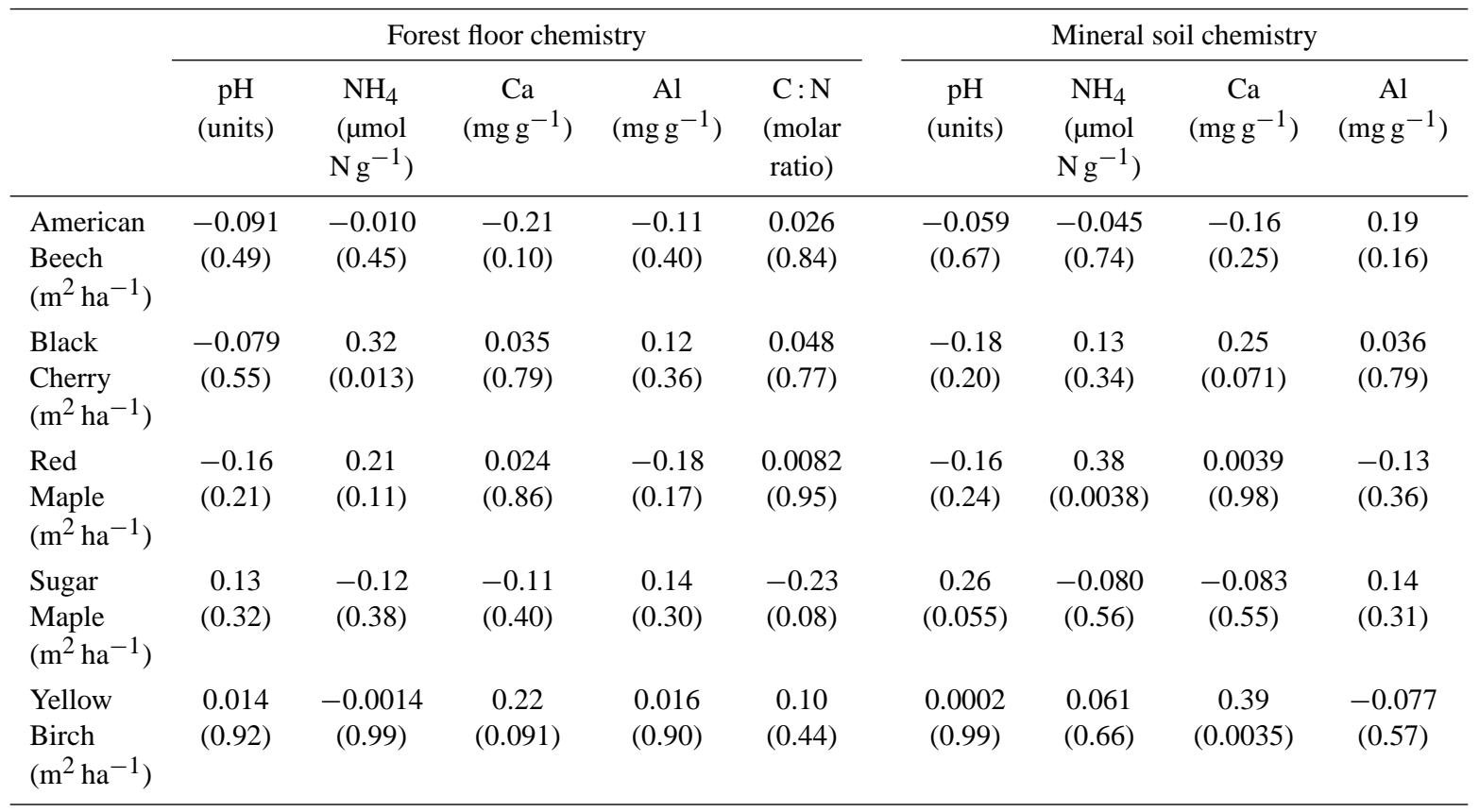

were significantly inversely correlated with sugar maple basal area $(r=-0.89, p=0.0077)$ (Table 4$)$.

\subsection{Black cherry site characteristics}

Forest floor $\mathrm{NH}_{4}$ and black cherry basal area exhibited a significant positive correlation $(r=0.32, p=0.013)$ (Table 3 ). Black cherry basal area was inversely correlated with stream water $\mathrm{BCS}, \mathrm{pH}, \mathrm{NO}_{3}^{-}$and $\mathrm{ANC}_{\mathrm{c}}(r=-0.52$, $p=0.23 ;-0.36,0.43 ;-0.55,0.20$ and $-0.51,0.24$, respectively) (Fig. 4b and Table 4). Stream water DOC concentrations were positively correlated with black cherry basal area $(r=0.26, p=0.58)$ (Table 4).

\subsection{Canonical correspondence analysis}

CCA is based on the correlations between tree species basal areas to forest floor, mineral soil and stream chemistry, in which these correlations are transformed to two ordination axes, similar to the first two principal components, to display the relationships between the species and chemistry in a biplot. However, the re-computed relationships are on the relative basis. Thus, the relative locations and directions are important and interesting. For example, in Fig. 5c, sugar maple is on the same direction as stream water $\mathrm{ANC}_{\mathrm{c}}, \mathrm{BCS}$ and $\mathrm{pH}$ and American beech is on the same direction as stream water $\mathrm{NO}_{3}^{-}$, which indicated positive association or relationships (as also shown in Table 4). But the length of the arrows for the stream chemistry was relative to their correlations with the species. For example, the arrow length of DOC was longest because it had the largest (negative) correlation with sugar maple (thus opposite direction) in Table 4. On the other hand, the biplot was overlaid from the two ordination systems (one for species and one for chemistry). The scaling of the two axes system may be different. Therefore, the relative directions of species vs. chemistry are more important than the relative locations of species vs. chemistry (e.g., how far away from each other).

The most important environmental variables associated with tree species basal area in the forest floor CCA biplot, as indicated by the longer arrows, were forest floor $\mathrm{Ca}$ and $\mathrm{NH}_{4}$ (Fig. 5a). The most important environmental variables associated with tree species basal area in the mineral soil CCA biplot were mineral soil $\mathrm{Ca}, \mathrm{NH}_{4}$ and $\mathrm{pH}$ (Fig. 5b). Forest floor $\mathrm{Al}$ and mineral soil $\mathrm{Al}$ were the least important environmental variables as indicated by the shortest arrows in the biplots (Fig. 5a, b). Stream water DOC was the most important environmental variable associated with tree species basal area in the stream water CCA biplot (Fig. 5c).

The relative location of black cherry in the CCA biplot indicated a strong positive association with forest floor $\mathrm{NH}_{4}$ (Table 3 and Fig. 5a). Both the forest floor and mineral soil CCA biplots indicated a strong positive association between yellow birch and Ca levels, a strong positive association between sugar maple and $\mathrm{pH}$ and a strong negative association between black cherry and $\mathrm{pH}$ (Fig. 5a, b). The relative location of sugar maple in the CCA biplot indicated a strong positive association between sugar maple and stream water $\mathrm{ANC}_{\mathrm{c}}, \mathrm{BCS}$ and $\mathrm{pH}$, and a strong positive association between American beech and stream water $\mathrm{NO}_{3}^{-}$(Fig. 5c). 

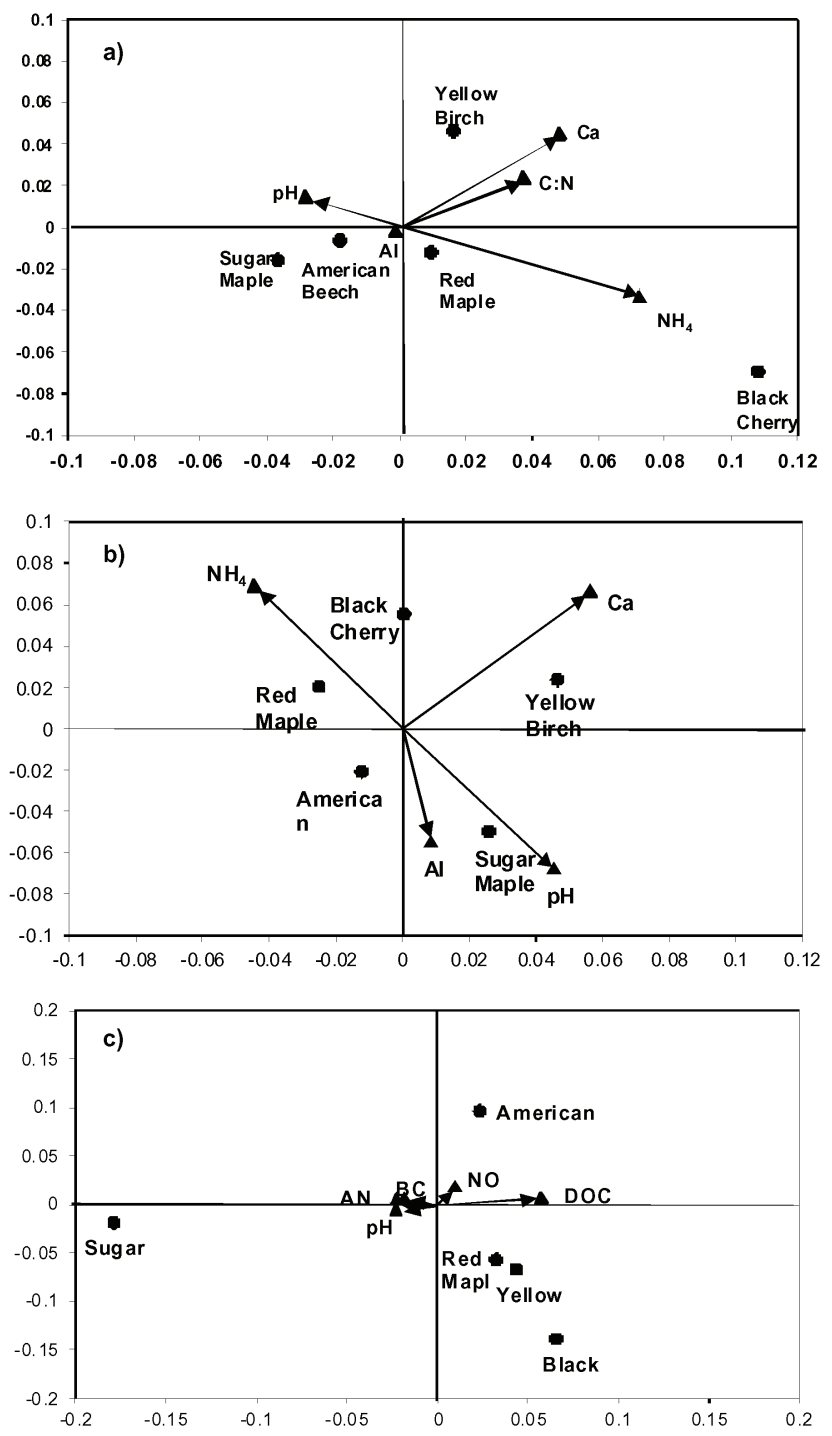

Fig. 5. CCA biplots with tree species basal area $\left(\mathrm{m}^{2} \mathrm{ha}^{-1}\right)$ represented by circles and environmental variables. The environmental variables (arrows) are (a) forest floor $\mathrm{pH}$ (units), $\mathrm{NH}_{4}$ ( $\left.\mu \mathrm{mol} \mathrm{Ng}^{-1}\right), \mathrm{Ca}\left(\mathrm{mg} \mathrm{g}^{-1}\right), \mathrm{Al}\left(\mathrm{mg} \mathrm{g}^{-1}\right)$ and $\mathrm{C}: \mathrm{N}$ (molar ratio); (b) mineral soil $\mathrm{pH}$ (units), $\mathrm{NH}_{4}\left(\mu \mathrm{mol} \mathrm{Ng}{ }^{-1}\right), \mathrm{Ca}\left(\mathrm{mg} \mathrm{g}^{-1}\right)$ and $\mathrm{Al}\left(\mathrm{mgg}^{-1}\right)$; and (c) stream sample $\mathrm{pH}$ (units), $\mathrm{NO}_{3}^{-}\left(\mu \mathrm{eq} \mathrm{L}^{-1}\right)$, DOC $\left(\mu \mathrm{mol} \mathrm{CL} \mathrm{L}^{-1}\right), \mathrm{ANC}_{\mathrm{c}}\left(\mu \mathrm{eq} \mathrm{L}^{-1}\right)$ and BCS $\left(\mu \mathrm{eq} \mathrm{L}^{-1}\right)$.

\section{Discussion and conclusion}

Northern hardwood forests are comprised of a mix of acid-intolerant and acid-tolerant species, primarily American beech, basswood, black cherry, eastern hemlock, red maple, red spruce, sugar maple, white ash, white pine and yellow birch (Braun, 1950). In northern hardwood stands in Pennsylvania and New York, sugar maple growth was positively related to foliar concentrations of $\mathrm{Ca}$ and $\mathrm{Mg}$ while co-occurring black cherry showed opposite growth responses with greater growth in stands with below-threshold
$\mathrm{Ca}$ and $\mathrm{Mg}$ compared with above-threshold stands (Long et al., 2009). Acidic deposition has accelerated the loss of exchangeable $\mathrm{Ca}$ and the mobilization of monomeric $\mathrm{Al}$ in forest stands resulting in the decline of sugar maple stands in the northeastern United States (Lawrence et al., 1999). Sugar maple decline has most predominantly occurred on ridge tops and on upper slopes, where soil base availability is much lower than at mid and low slopes on the landscapes (Bailey et al., 2004). In forest stands with substantial tree mortality between 1989 and 1994, within the Alleghany National Forest, Pennsylvania, the dominant tree species has shifted from sugar maple to black cherry and red maple (McWilliams et al., 1996). Such a shift in three species composition would be consistent with a shift to more acid-tolerant tree species.

In Grass Pond watershed, forest composition is dominated by red maple and American beech with black cherry and sugar maple only comprising 4 and $9 \%$ relative basal area, respectively. At Grass Pond watershed, sugar maple basal area was associated with watershed attributes associated with the neutralization of atmospheric acidic inputs, including high stream water $\mathrm{ANC}_{\mathrm{c}}, \mathrm{BCS}$ and $\mathrm{pH}$, low stream water DOC and high soil $\mathrm{pH}$. These locations were in contrast to those in which black cherry was found that showed more acidic attributes (Fig. 6). Other research has suggested that sugar maple tree characteristics, such as high $\mathrm{Ca}$ concentrations and low $\mathrm{C}: \mathrm{N}$ ratio leaf litter, will result in high mineralization and nitrification rates within the soil, contributing to increased nutrient cycling and nitrate leaching (Christ et al., 2002; Lovett and Rueth, 1999; Page and Mitchell, 2008). The associations between sugar maple basal area and high stream water high ANC and low stream water DOC indicates deep sub-surface hydrological flow paths through thick mineral soil layers and parent material (Fig. 6) (Chen et al., 1984; Mitchell et al., 2013; Driscoll and Peters, 1987). In general, sites with thick soil layers with relatively high soil $\mathrm{pH}$ and Ca concentrations are more likely to be colonized by sugar maple trees than other less suitable more acidic sites because of the relatively high nutrient demands of this tree species (Bailey et al., 2004; Burns and Honkala, 1990; Christopher et al., 2006; Van Breemen et al., 1997).

As a shade intolerant, early successional species, black cherry is associated with shallow soils on steep slopes where blowdowns and other disturbances create gaps that allow adequate sunlight for black cherry regeneration and growth (Aguilar and Arnold, 1985). At Grass Pond watershed, black cherry basal area was associated with those watershed attributes associated with the inability to neutralize atmospheric acidic inputs, including low stream water $\mathrm{ANC}_{\mathrm{c}}$, $\mathrm{BCS}$ and $\mathrm{pH}$, high stream water $\mathrm{DOC}$ and total $\mathrm{Al}$, low soil $\mathrm{Ca}$ concentrations, and high $\mathrm{C}: \mathrm{N}$ ratios (Fig. 6). The negative association between black cherry basal area and stream water $\mathrm{ANC}_{\mathrm{c}}$ and $\mathrm{BCS}$ and the positive association with stream water DOC is likely due to black cherry stands occurring on relatively steep slopes with thin soils and due to the predominance of shallow flow paths through forest floor 
Table 4. Factor analysis. Watershed average stream chemistry data and tree species basal area Pearson correlation coefficients $(n=7)$ with $p$ values.

\begin{tabular}{|c|c|c|c|c|c|}
\hline & \multicolumn{5}{|c|}{ Stream chemistry } \\
\hline & $\begin{array}{r}\mathrm{pH} \\
\text { (units) }\end{array}$ & $\begin{array}{r}\mathrm{NO}_{3}^{-} \\
\left(\mu \mathrm{eq} \mathrm{L}^{-1}\right)\end{array}$ & $\begin{array}{r}\text { DOC } \\
\left(\mu \mathrm{mol} \mathrm{CL} L^{-1}\right)\end{array}$ & $\begin{array}{r}\mathrm{ANC}_{\mathrm{c}} \\
\left(\mu \mathrm{eq} \mathrm{L}^{-1}\right)\end{array}$ & $\begin{array}{r}\text { BCS } \\
\left(\mu \mathrm{eq} \mathrm{L}^{-1}\right)\end{array}$ \\
\hline $\begin{array}{l}\text { American Beech } \\
\left(\mathrm{m}^{2} \mathrm{ha}^{-1}\right)\end{array}$ & $-0.037(0.94)$ & $0.74(0.056)$ & $0.43(0.34)$ & $0.19(0.69)$ & $0.15(0.75)$ \\
\hline $\begin{array}{l}\text { Black Cherry } \\
\left(\mathrm{m}^{2} \mathrm{ha}^{-1}\right)\end{array}$ & $-0.36(0.43)$ & $-0.55(0.20)$ & $0.26(0.58)$ & $-0.51(0.24)$ & $-0.52(0.23)$ \\
\hline $\begin{array}{l}\text { Red Maple } \\
\left(\mathrm{m}^{2} \mathrm{ha}^{-1}\right)\end{array}$ & $0.023(0.96)$ & $-0.22(0.64)$ & $0.037(0.94)$ & $-0.19(0.69)$ & $-0.19(0.69)$ \\
\hline $\begin{array}{l}\text { Sugar Maple } \\
\left(\mathrm{m}^{2} \mathrm{ha}^{-1}\right)\end{array}$ & $0.39(0.39)$ & $-0.17(0.72)$ & $-0.89(0.0077)$ & $0.25(0.59)$ & $0.32(0.48)$ \\
\hline $\begin{array}{l}\text { Yellow Birch } \\
\left(\mathrm{m}^{2} \mathrm{ha}^{-1}\right)\end{array}$ & $0.44(0.32)$ & $0.11(0.82)$ & $0.15(0.75)$ & $0.25(0.59)$ & $0.23(0.62)$ \\
\hline
\end{tabular}

Sugar Maple Site

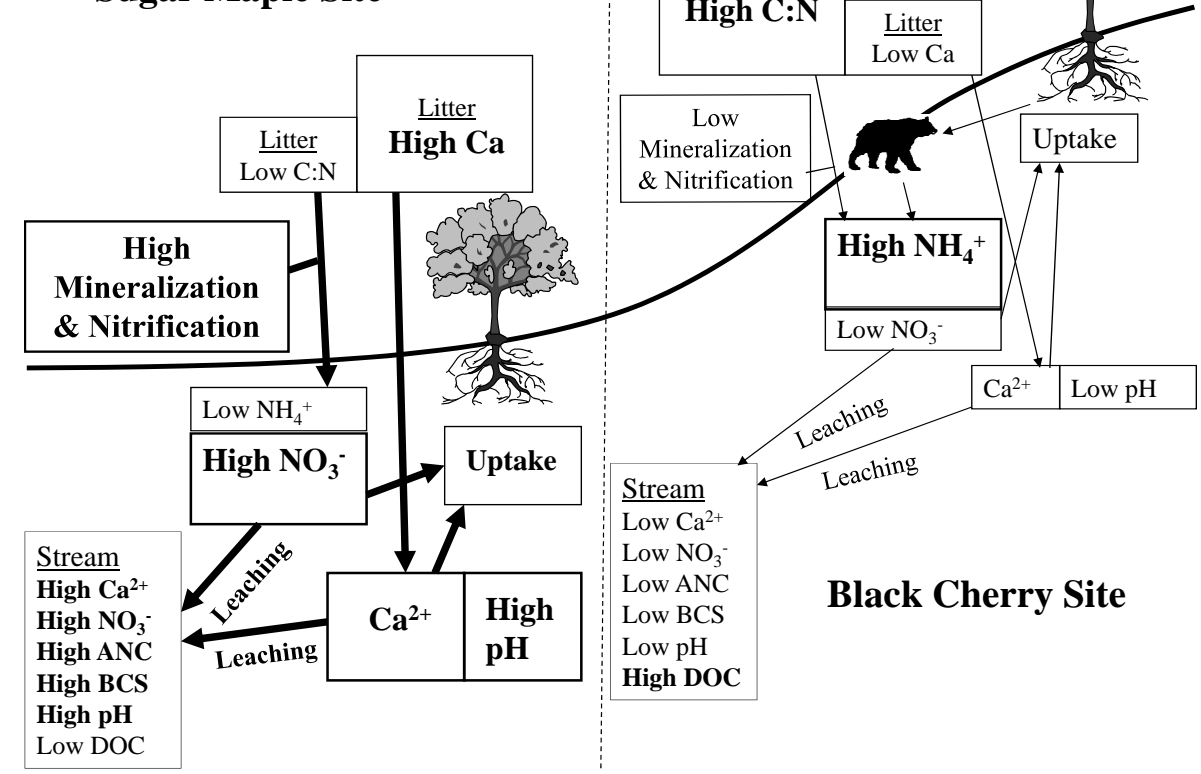

Fig. 6. Conceptual model indicating the dominant factors controlling the variation in stream water chemistry between sites with similar atmospheric deposition and land use but varying tree species and soil processes in a northern hardwood dominated ecosystem. Thicker arrows indicate relatively greater fluxes and larger boxes indicate relatively larger pools between sites.

soil layers (Fig. 6). The significantly positive correlation between black cherry basal area and forest floor $\mathrm{NH}_{4}^{+}$concentrations, indicates slow decomposition of black cherry litter that is relatively low in nutrient base cations (Fig. 6). Other research has also found that the basal area of acid-tolerant tree species was inversely correlated with nitrification rates due to leaf litter nutrient concentrations and associated $\mathrm{C}: \mathrm{N}$ ratios (Christ et al., 2002; Finzi et al., 1998; Mitchell et al., 2003; Ross et al., 2009). Within the upper elevations of Grass
Pond subwatershed 5 where black cherry groves were identified, fresh black bear scat loaded with black cherry seeds was observed during early October field sampling, indicating a bear den in the area. The high frequency and distribution of black cherry trees within this portion of the subwatershed may be related to locations of disturbances that would allow light necessary for black cherry growth and also related to seed dispersal by black bear movements (Fig. 6). 
The limited significant statistical relationships between tree species basal area, stream and soil chemistry was most likely due to the limited presence of sugar maple and black cherry within Grass Pond watershed, generally low soil $\mathrm{Ca}$ concentrations, low variations in soil $\mathrm{Ca}$ concentrations among plots as related to species composition and the lack of mineral and forest floor soil development in the high elevation and steep sloped plots resulting in a decreased soil sample size and a small watershed stream chemistry sample size. These soil conditions combined with influences of the vegetation components are the major drivers affecting the spatial variation in the surface water chemistry of the Grass Pond watershed. Although correlations have been identified between tree species basal area, soil chemistry and stream chemistry, it is unclear whether the presence of sugar maple (conversely, black cherry) in base-rich soils was due to sugar maple contributing base-rich nutrients to the forest floor or if it was due to base-rich soils promoting sugar maple growth.

Documented disturbance history indicates that trees within Grass Pond watershed were likely logged and burned over 100 years ago, potentially influencing soil, vegetation and stream characteristics of the watershed. Other studies have found that in the short term following a disturbance, northern hardwood watersheds in New Hampshire exhibited an increase in stream water $\mathrm{NO}_{3}^{-}, \mathrm{Al}$ and base cations, and a decrease in stream water $\mathrm{SO}_{4}$ and $\mathrm{pH}$ (Lawrence et al., 1987). Additionally, other studies have found that forests in the Adirondack Mountains of New York, with varying disturbance histories have similar soil $\mathrm{C}: \mathrm{N}$ ratios, net $\mathrm{N}$ mineralization rates and net nitrification rates (Latty et al., 2004).

Previous research has shown that sugar maple is acid intolerant or a calciphilic tree species, and our results provide additional information that supports that black cherry is an acid-tolerant tree species and hence may be associated with those areas with low surface water ANC and $\mathrm{pH}$ values. Similarly, sugar maple presence is a good indicator of basic soil and stream conditions compared to stands containing black cherry. These soil and site characteristics are not only important in determining which tree species colonize an area but also ultimately affect how these tree species will concomitantly influence soil and forest patterns including variations in litter nutrient concentrations and mineralization rates and hence surface water characteristics (Christ et al., 2002; Lovett and Rueth, 1999; Page and Mitchell, 2008).

Our results show that black cherry has a distinctive positive relationship with forest floor $\mathrm{NH}_{4}$, while sugar maple has a distinctive inverse relationship with stream water DOC concentrations. Understanding the interactions among tree species and watershed acid-base status provides insight into the sensitivity or resilience of the watershed to inputs of acidic deposition. The continual depletion of base cations from northern hardwood forest soil, primarily due to the effects of acidic deposition, will reduce the area favorable for growing sugar maple and increase area available for black cherry and other acid-tolerant tree species. Shifts in the tree species from those that require relatively high soil base concentrations such as sugar maple to those acid-tolerant species such as black cherry could have major impacts on these forest ecosystems and their associated surface waters. Future shifts in tree species composition and soil nutrient dynamics will presumably be accompanied by concomitant shifts in stream chemistry throughout the watershed. These evaluations of the spatial and temporal patterns of soil and surface water chemistry in northern hardwood forests provide new insights into the continued and long-term effects of acidic deposition on forested watersheds.

Acknowledgements. This research was partially supported by the New York State Energy Research Development Authority (NYSERDA) Environmental Monitoring, Evaluation and Protection (EMEP) program and by SUNY ESF's Graduate Student Association "Research In Need" Grant. The New York State Department of Environmental Conservation permitted sample collection within the Ha-De-Ron-Dah Wilderness Area. The authors thank Pat McHale, David Lyons, Chuck Schirmer, Laura Hartley, Harold and Donna McEathron and William Foley for help on this research both in the field and in the laboratory. Also thanks to Greg Lawrence, John Stella, and Martin Dovciak who reviewed earlier versions of this manuscript.

The views and opinions of the author expressed herein do not necessarily state or reflect those of the United States Environmental Protection Agency.

Edited by: A. D. Reeves

\section{References}

Aber, J. D., Goodale, C. L., Olllinger, S. V., Smith, M., Magill, A. H., Martin, M. E., Hallett, R. A., and Stoddard, J. L.: Is nitrogen deposition altering the nitrogen status of northeastern forests?, Bioscience, 53, 375-389, 2003.

Adams, M. B. and Angradi, T. R.: Decomposition and nutrient dynamics of hardwood leaf litter in the Fernow Whole-Watershed Acidification Experiment, Forest Ecol. Manage., 83, 61-69, 1996.

Aguilar, R. and Arnold, R. W.: Soil- landscape relationships of a climax forest in the Alleghany high plateau, Pennsylvania, Soil Sci. Soc. Am., 49, 695-701, 1985.

Bailey, S. W., Horsley, S. B., Long, R. P., and Hallett, R. A.: Influence of edaphic factors on sugar maple nutrition and health on the Allegheny Plateau, Soil Sci. Soc. Am., 68, 243-252, 2004.

Blume, L. J., Schumacher, B. A., Schaffer, P. W., Cappo, K. A., Papp, M. L., Van Remortal, R. D., Coffey, D. S., Johnson, M. G., and Chaloud, D. J.: Handbook of methods for acid deposition studies: Laboratory analysis for soil chemistry, United States Environmental Protection Agency EPA/600/4-90/023, Washington, D.C., 1990.

Braun, E. L.: Deciduous forests of eastern North America, The Blakiston Co., Philadelphia, PA, 1950. 
Burns, R. M. and Honkala, B. H. (tech. Coords.): Silvics of North America: 1. Conifers; 2. Hardwoods Agriculture Handbook 654, US Dept. of Agriculture, Forest Service, Washington, D.C., vol. 2, 1990.

Chen, C. W., Gherini, S. A., Peters, N. E., Murdoch, P. S., Newton, R. M., and Goldstein, R. A.: Hydrological analysis of acidic and alkaline lakes, Water Resour. Res., 20, 1875-1882, 1984.

Christ, M. J., Peterjohn, W. T., Cumming, J. R., and Adams, M. B.: Nitrification potentials and landscape, soil and vegetation characteristics in two Central Appalachian watersheds differing in $\mathrm{NO}_{3}^{-}$ export, Forest Ecol. Manage., 159, 145-158, 2002.

Christopher, S. F., Page, B. D., Campbell, J. L., and Mitchell, M. J.: Contrasting stream water $\mathrm{NO}_{3}^{-}$and $\mathrm{Ca}^{2+}$ in two nearly adjacent catchments: the role of soil $\mathrm{Ca}$ and forest vegetation, Global Change Biol., 12, 362-381, 2006.

Cronan, C. S. and Grigal, D. F.: Use of calcium/aluminum ratios as indicators of stress in forest ecosystems, J. Environ. Qual., 24, 209-226, 1995.

Dijkstra, F.A.: Calcium mineralization in the forest floor and surface soil beneath diff erent tree species in the northeastern US, Forest Ecol. Manage., 175, 185-194, 2003.

Driscoll, C. T. and Peters, N. E.: Hydrogeological controls on surface water chemistry in the Adirondack region of New York State, Biogeochemistry, 3, 163-180, 1987.

Driscoll, C. T. and Newton, R. M.: Chemical characteristics of Adirondack lakes, Environ. Sci. Technol., 19, 1018-1024, 1990.

Driscoll, C. T., Newton, R. M., Gubala, C. P., Baker, J. P., and Christensen, S.: Adirondack Mountains, in: Acidic Deposition and Aquatic Ecosystems: Regional Case Studies, edited by: Charles, D. F., Springer-Verlag, New York, 133-202, 1991.

Driscoll, C. T., Lawrence, G. B., Bulger, A. J., Butler, T. J., Cronan, C. S., Eagar, C., Lambert, K. F., Likens, G. E., Stoddard, J. L., and Weathers, K. C.: Acidic deposition in the Northeastern United States: Sources and inputs, ecosystem effects and management strategies, Bioscience, 51, 181-198, 2001.

Driscoll, C. T., Whitall, D., Aber, J., Boyer, E., Castro, M., Cronan, C., Goodale, C., Groffman, P., Hopkinson, C., Lambert, K., Lawrence, G., and Ollinger, S.: Nitrogen pollution in the Northeastern United States: Sources, effects, and management options, Bioscience, 53, 357-373, 2003.

Duchesne, L., Ouimet, R., Moore, J. D., and Paquin, R.: Changes in structure and composition of maple-beech stands following sugar maple decline in Quebec, Canada, Forest Ecol. Manage., 208, 223-236, 2005.

Finzi, A. C., Van Breemen, N., and Canham, C. D.: Canopy treesoil interactions within temperate forests: Species effects on soil carbon and nitrogen, Ecol. Appl., 8, 440-446, 1998.

Fujinuma, R., Bockheim, J., and Balster, N.: Base-cation cycling by individual tree species in old-growth forests of Upper Michigan, USA, Biogeochemistry, 74, 357-376, 2005.

Godefroid, S., Phartyal, S. S., Weyembergh, G., and Koedam, N.: Ecological factors controlling the abundance of non-native invasive black cherry (Prunus serotina) in deciduous forest understory in Belgium, Forest Ecol. Manage., 210, 91-105, 2005.

Gray, D. V.: First 5-year revision to Ha-De-Ron-Dah Wilderness unit management plan, New York State Department of Environmental Conservation, New York, 1995.

Hobbie, S. E.: Effects of plant species on nutrient cycling, Tree, 7, 336-339, 1992.
Hodge, L. M. and Naik, D. N.: Canonical correspondence analysis in SAS software, in: Proceedings of the 24th Annual SAS Users Group International Conference, Cary, NC, 1607-1613, 1999.

Horsley, S. B., Long, R. P., Bailey, S. W., and Hall, T. J.: Factors associated with the decline of sugar maple on the Allegheny Plateau, Can. J. Forest Res., 30, 1365-1378, 2000.

Ito, M., Mitchell, M. J., and Driscoll, C. T.: Spatial patterns of precipitation quantity and chemistry and air temperature in the Adirondack region of New York, Atmos. Environ., 36, 10511062, 2002.

Ito, M., Mitchell, M. J., Driscoll, C. T., Newton, R. M., Johnson, C. E., and Roy, K. M.: Controls on surface water chemistry in two lake-watersheds in the Adirondack region of New York: Differences in nitrogen solute sources and sinks, Hydrol. Process., 21, 1249-1264, 2007.

Khattree, R. and Naik, D. N.: Multivariate data reduction and discrimination with SAS software, SAS Institute Inc., Carry, NC, 558-584, 2000.

Latty, E. F., Canham, C. D., and Marks, P. L.: The effects of landuse history on soil properties and nutrient dynamics in northern hardwood forests of the Adirondack Mountains, Ecosystems, 7, 193-207, 2004.

Lawrence, G. B., Fuller, R. D., and Driscoll, C. T.: Release of aluminum following whole-tree harvesting at the Hubbard Brook Experimental Forest, New Hampshire, J. Environ. Qual. 16, 383390, 1987.

Lawrence, G. B., David, M. B., Bailey, S. W., and Shortle, W. C.: Assessment of calcium status in soils of red spruce forests in the northeastern United States, Biogeochemistry, 38, 19-39, 1997.

Lawrence, G. B., David, M. B., Lovett, G. M., Murdoch, P. S., Burns, D. A., Stoddard, J. L., Baldigo, B. P., Porter, J. H., and Thompson, A. W.: Soil calcium status and the response of stream chemistry to changing acidic deposition rates, Ecol. Appl., 9, 1059-1072, 1999.

Lawrence, G. B., Sutherland, J. W., Boylen, C. W., NierzwickiBauer, S. W., Momen, B., Baldigo, B. P., and Simonin, H. A.: Acid rain effects on aluminum mobilization clarified by inclusion of strong organic acids, Environ. Sci. Technol., 41, 93-98, 2007.

Long, R. P., Horsley, S. B., and Lilja, P. R.: Impact of forest liming on growth and crown vigor of sugar maple and associated hardwoods, Can. J. Forest Res., 27, 1560-1573, 1997.

Long, R. P., Horsley, S. B., Hallett, R. A., and Bailey, S. W.: Sugar maple growth in relation to nutrition and stress in the northeastern United States, Ecol. Appl., 19, 1454-1466, 2009.

Lorenz, K., Preston, C. M., Krumrei, S., and Feger, K.: Decomposition of needle/leaf litter from Scots pine, black cherry, common oak and European beech at a conurbation forest site, Eur. J. Forest Res., 123, 177-178, 2004.

Lovett, G. M. and Rueth, H.: Soil nitrogen transformations in beech and maple stands along a nitrogen deposition gradient, Ecol. Appl., 9, 1330-1344, 1999.

MacAvoy, S. E. and Bulger, A. J.: Survival of brook trout (Salvelinus fontinalis) embryos and fry in streams of different acid sensitivity in Shenandoah National Park, USA, Water Air Soil Poll., 85, 445-450, 1995.

McFee, W. W., Kelly, J. M., and Beck, R. H.: Acid precipitation effects on soil $\mathrm{pH}$ and base saturation of exchange sites, Water Air Soil Poll., 7, 401-408, 1977. 
McWilliams, W. H., White, R., Arner, S. L., Nowak, C. A., and Stout, S. L.: Characteristics of declining forest stands on the Allegheny National Forest, United States Department of Agriculture Forest Service, Radnor, PA, 1996.

Melillo, J. M., Aber, J. D., and Muratore, J. F.: Nitrogen and lignin control of hardwood leaf litter decomposition dynamics, Ecology, 63, 621-626, 1982.

Mitchell, M. J., Foster, N. W., Shepard, J. P., and Morrison, I. K.: Nutrient cycling in Huntington forest and Turkey lakes deciduous stands: nitrogen and sulfur, Can. J. Forest Res., 22, 457-464, 1992.

Mitchell, M. J., Driscoll, C. T., Inamdar, S., McGee, G. G., Mbila, M. O., and Raynal, D. J.: Nitrogen biogeochemistry in the Adirondack Mountains of New York: Hardwood ecosystems and associated surface waters, Environ. Poll., 123, 355-364, 2003.

Mitchell, M. J., Driscoll, C.T ., McHale, P. J., Roy, K. M., and Dong, Z.: Lake-watershed sulfur budgets and their response to decreases in atmospheric sulfur deposition: Watershed and climate controls, Hydrol. Process., 27, 710-720, 2013.

Moore, J., Ouimet, R., and Duschesne, L.: Soil and sugar maple response 15 years after dolomitic lime application, Forest Ecol. Manage., 281, 130-139, 2012.

Page, B. D. and Mitchell, M. J.: The influence of basswood (Tilia americana) and soil chemistry on soil nitrate concentrations in a northern hardwood forest, Can. J. Forest Res., 38, 667-676, 2008.

Ross, D. S., Wemple, B. C., Jamison, A. E., Fredriksen, G., Stanley, J. B., Lawrence, G. B., Bailey, S. W., and Campbell, J. L.: A cross-site comparison of factors influencing soil nitrification rates in northeastern USA forested watersheds, Ecosystems, 12, 158-178, 2009.
Schneider, P.: The Adirondacks: A History of America's First Wilderness, Henry Holt and Company, LLC, New York, 1998.

Sparks, D. L., Page, A. L., Helmke, P. A., Loeppert, R. H., Soltanpour, P. N., Tabatabai, M. A., Johnston, C. T., and Sumner, M. E. (Eds.): Methods of Soil Analysis: Part 3 Chemical Methods, Soil Science of America, Inc., Madison, Wisconsin, 1996.

Sterne, J. A. C. and Smith, G. D.: Sifting the evidence-what's wrong with significance tests?, British Med. J., 322, 226-231, 2001.

Sullivan, T. J., Fernandez, I. J., Herlihy, A. T., Driscoll, C. T., McDonnell, T. C., Nowicki, N. A., Snyder, K. U., and Sutherland, J. W.: Acid-base characteristics of soils in the Adirondack Mountains, New York, Soil Sci. Soc. Am., 70, 141-152, 2006.

Ter Braak, C. J. F.: Canonical correspondence analysis: A new eigenvector technique for multivariate direct gradient analysis, Ecology, 67, 1167-1179, 1986.

Van Breemen, N.: Nutrient cycling strategies, Plant Soil, 168-169, 321-326, 1995.

Van Breemen, N., Finzi, A. C., and Canham, C. D.: Canopy treesoil interactions within temperate forests: effects of soil elemental composition and texture on species distributions, Can. J. Forest Res., 27, 1110-1116, 1997.

Wilde, S. A., Voight, G. K., and Iyer, J. C.: Soil and plant analysis for tree culture, Oxford and IBH Publishing Co., New Delhi, India, 1972. 